\title{
WPEYW PILOTA NA WŁAŚCIWOŚCI DRGANIOWE UKŁADÓW STEROWANIA LEKKICH SAMOLOTÓW
}

\author{
WieSŁAW KRZYMIEŃ \\ Sieć Badawcza Lukasiewicz - Instytut Lotnictwa, Warszawa \\ e-mail: wieslaw.krzymien@ilot.lukasiewicz.gov.pl
}

\begin{abstract}
Analiza właściwości aeroelastycznych konstrukcji latających jest wymagana przepisami budowy. Elementem analizy są badania rezonansowe konstrukcji, których wyniki są potrzebne do wykonania obliczeń, jak również stanowią podstawę przeprowadzenia badań dowodowych w locie. Badania rezonansowe obejmują także układy sterowania w zakresie wychylania lub skręcania powierzchni sterowych. W przypadku konstrukcji lekkich i ultralekkich oddziaływanie pilota może istotnie zmienić właściwości drganiowe układów sterowania. Przeprowadzone badania miały na celu określenie wpływu pilota na układ sterowania przez dołożenie masy ręki i sztywności ramienia do drążka oraz nóg do pedałów. Wyniki pomiarów pozwalają na dobranie masy zastępczej ręki lub rąk oraz nóg podczas badań rezonansowych, a także uwzględnienie jej w obliczeniach właściwości flatterowych lekkich konstrukcji. W artykule przedstawiono metodę pomiarów oraz podstawowe wyniki badań przeprowadzonych na specjalnie przygotowanym stanowisku.
\end{abstract}

Stowa kluczowe: badania naziemne, układ sterowania, flatter, oddziaływanie pilota

\section{Wprowadzenie}

Bezpieczeństwo od flatteru, czyli drgań samowzbudnych każdej konstrukcji latającej, jest wymagane przepisami budowy np. FAR lub CS [1]. Postacią drgań samowzbudnych występującą przy niewłaściwym lub niewystarczającym wyważeniu powierzchni sterowych jest flatter z ich udziałem. Typowym postępowaniem dla każdej nowej konstrukcji jest przeprowadzenie badań rezonansowych $\mathrm{w}$ zakresie niskich częstotliwości, a na podstawie ich wyników (częstotliwości i postaci drgań własnych) wykonanie odpowiednich obliczeń analizujących możliwość wystąpienia flatteru (np. [2]). Badania właściwości drganiowych powierzchni sterowych obejmują także układy sterowania (np. [3]). Na rysunku 1 pokazano wzbudzanie drgań steru wysokości podczas naziemnych badań rezonansowych (ang. GVT) motoszybowca w SB€-Instytucie Lotnictwa.

Konstrukcje lekkie, jakimi są małe samoloty, szybowce, a także śmigłowce i wiatrakowce, posiadają zwykle popychaczowe układy sterowania bez wzmacniaczy (którego typowy schemat przedstawia rys. 2.), a elementem sterowania jest drążek lub wolant oraz pedały. Ich masa ulega zmianie ze względu na oddziaływanie pilota: masa jego ręki lub stóp mają wpływ na częstotliwości wychylania powierzchni sterowych. Badania rezonansowe obiektów latających ze względu na czas trwania jak i warunki ich wykonywania przeprowadza się bez udziału pilota. Podczas takich badań obiekt zostaje elastyczne zawieszony (np. na gumowych sznurach), a w miejsce pilota układa się odpowiednio rozłożone masy zastępcze.

Podstawowe badania rezonansowe wykonuje się z drążkiem i pedałami swobodnymi. Pomiary drgań własnych postaci, w których występuje wychylanie sterów, przeprowadza się ponownie, wprowadzając zastępczą masę ręki lub stóp jako masę mocowaną do drążka lub wolanta oraz pedałów, otrzymując wpływ określonej masy zastępczej ręki lub nóg. Dla szybowców lub lekkich samolotów przyjęto mocować do drążka masę $1 \mathrm{~kg}$ (rys. 3) oraz $1 \mathrm{~kg}$ do każdego pedału. 


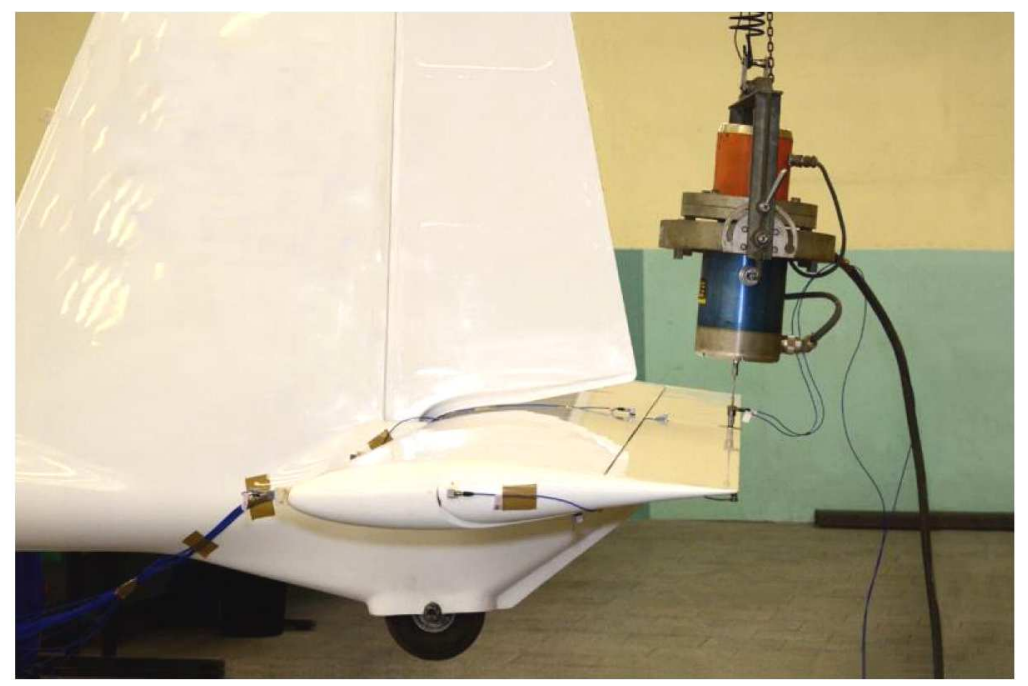

Rys. 1. Badania rezonansowe układu sterowania sterem wysokości

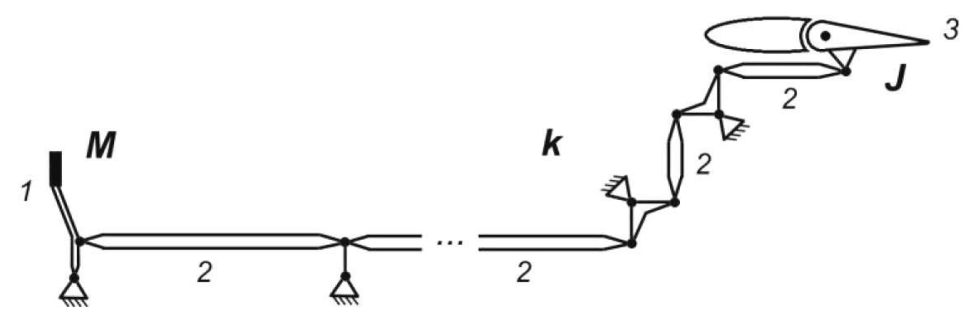

Rys. 2. Ogólny schemat popychaczowego układu sterowania: 1 - drążek, 2 - popychacze, 3 - ster

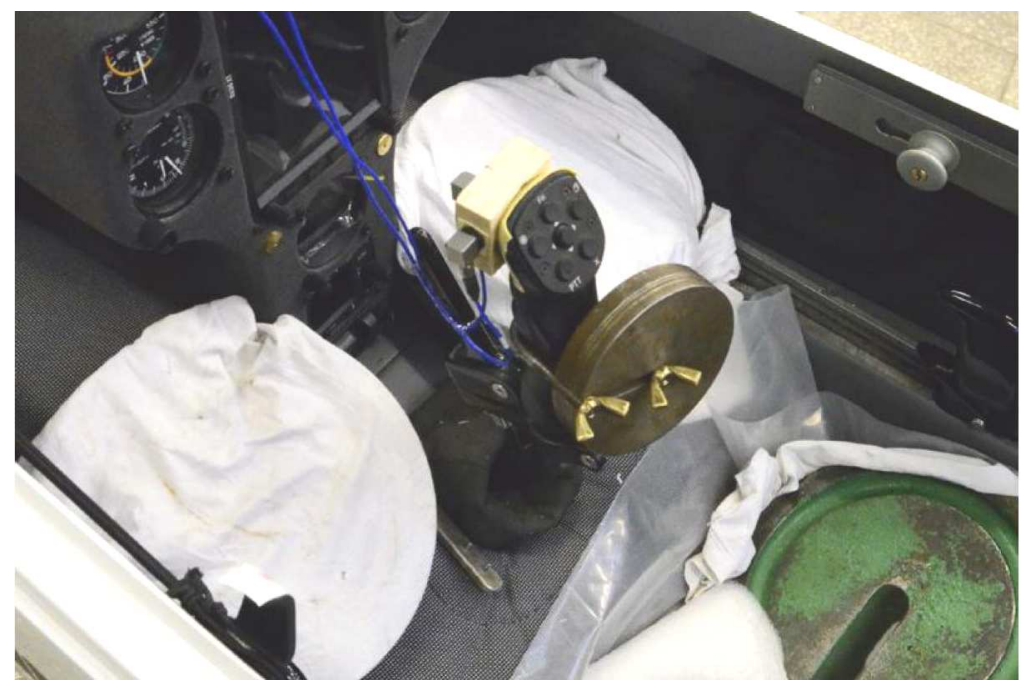

Rys. 3. Masa zastępcza (1 kg) zamocowana do drążka podczas badań rezonansowych szybowca

W niektórych ośrodkach badania rezonansowe z udziałem układów sterowania przeprowadza się przy swobodnym, a następnie przy zablokowanym drążku lub pedałach - w miarę możliwości ich zamocowania w kabinie. W praktyce wykonanie odpowiedniej blokady drążka i pedałów bywa kłopotliwe ze względu na jej niedostateczną sztywność.

Rozwiązaniem opartym na pomiarach statycznych jest oszacowanie właściwości drganiowych układu sterowania na podstawie masy wszystkich jego elementów oraz pomiaru rzeczywistej sztywności (statycznej) układu. Pomiary takie wykonuje się podczas sprawdzania wytrzymałości statycznej układów sterowania. Badania (obejmujące także mocowanie steru wraz z układem 
popychaczy) przeprowadza się na wstępnym etapie opracowań prototypu (np. [4]). Wyniki z obliczeń (np. MES) wprowadza się następnie do obliczeń właściwości aeroelastycznych powierzchni sterowych.

Innym sposobem określenia właściwości drganiowych układów sterowania jest rozdzielenie badań rezonansowych obiektu. W pierwszym etapie wykonuje się zblokowanie sterów ze statecznikiem albo lotek ze skrzydłem (np. taśmą klejącą lub specjalnymi obejmami) i przeprowadza badania rezonansowe takiego obiektu. W następnym etapie wykonuje się badania rezonansowe poszczególnych układów sterowania możliwie sztywno (za pomocą podpór i obciążników), unieruchamiając skrzydła oraz stateczniki, pozostawiając drążek i pedały swobodne.

Na podstawie relacji pilotów można stwierdzić, że oddziaływanie pilota na drgający ster może być różne (np. indywidualne trzymanie steru), a także zależne od częstotliwości drgań. Wynikiem przeprowadzonych badań miało być oszacowanie wielkości dokładanej masy przez pilota do układu sterowania. Masę tę można określić jako masę zredukowaną do miejsca przyłożenia (uchwytu drążka albo pedałów) oraz jako zastępczą - zależną od właściwości dynamicznych ręki (rąk lub nóg), będącą wynikiem napięcia mięśni oraz kinematyki ręki lub nogi wynikającym z ułożenia ciała. Modelem pilota jest układ mas:

- dłoń-przedramię-ramię-tułów-oparcie fotela,

- stopa-goleń-udo-tułów-siedzisko i oparcie fotela,

połączonych przegubowo, z udziałem sztywności mięśni (oraz ich tłumieniem).

Na podstawie wyników przeprowadzonych badań będzie można podczas badań rezonansowych dobrać masy zastępcze w zależności od częstotliwości badanej postaci drgań układu sterowania, a także uwzględnić je w obliczeniach właściwości aeroelastycznych (flatterowych) konstrukcji.

Badania nie miały na celu określenia dynamicznego oddziaływania pilota, które mogłoby wywołać niskoczęstotliwościowe oscylacje konstrukcji w locie, a określane jako PIO (ang. Pilot Indicated Oscillation, np. [5]).

\section{Stanowisko i zakres badań}

Badania przeprowadzono na makiecie fotela pilota z elementami sterowania (rys. 4), którego drążek jak i mechanizm pedałów nie miały elementów sprężystych ani tłumiących. Do drążka, a następnie do układu pedałów podłączono elektrodynamiczny wzbudnik drgań o skoku cewki ok. $\pm 12 \mathrm{~mm}$. Na drążku oraz na lewym pedale w pobliżu miejsca wzbudzania drgań umieszczono czujnik przyspieszeń. Indukcyjny czujnik położenia był zamontowany do drążka w jego dolnej części (rys. 4), natomiast przy pedałach do ramienia prawego pedału bliżej osi obrotu (rys. 6). Wzbudzanie drgań następowało poprzez stalowy pręt i głowicę impedancyjną (tj. z czujnikami siły i przyspieszeń) - rys. 5 i 6.

Program badań obejmował:

- wyznaczenie masy zredukowanej drążka oraz pedałów wraz z czujnikami,

- wyznaczenie masy dodanej przez pilota do drążka oraz pedałów.

Badania przeprowadzono w zakresie częstotliwości 4-20 Hz dla różnych poziomów sił wzbudzenia drgań. Przyjęty zakres częstotliwości wynika z częstotliwości flatteru możliwego do wystąpienia w konstrukcjach lekkich o maksymalnej prędkości lotu do ok. $250 \mathrm{~km} / \mathrm{h}$ (np. [6]). Dolna częstotliwość pomiarów jest nieco większa od granicznej częstotliwości aktywnego oddziaływania pilota, tj. częstotliwości, przy której możliwe jest cykliczne przeciwdziałanie siłą ruchom oscylacyjnym. Z relacji osób biorących udział w badaniach (jak i zarejestrowanych drgań), częstotliwości graniczne to ok. $3 \mathrm{~Hz}$ dla drążka i ok. $2 \mathrm{~Hz}$ dla pedałów. Na przyjęcie takiego zakresu 


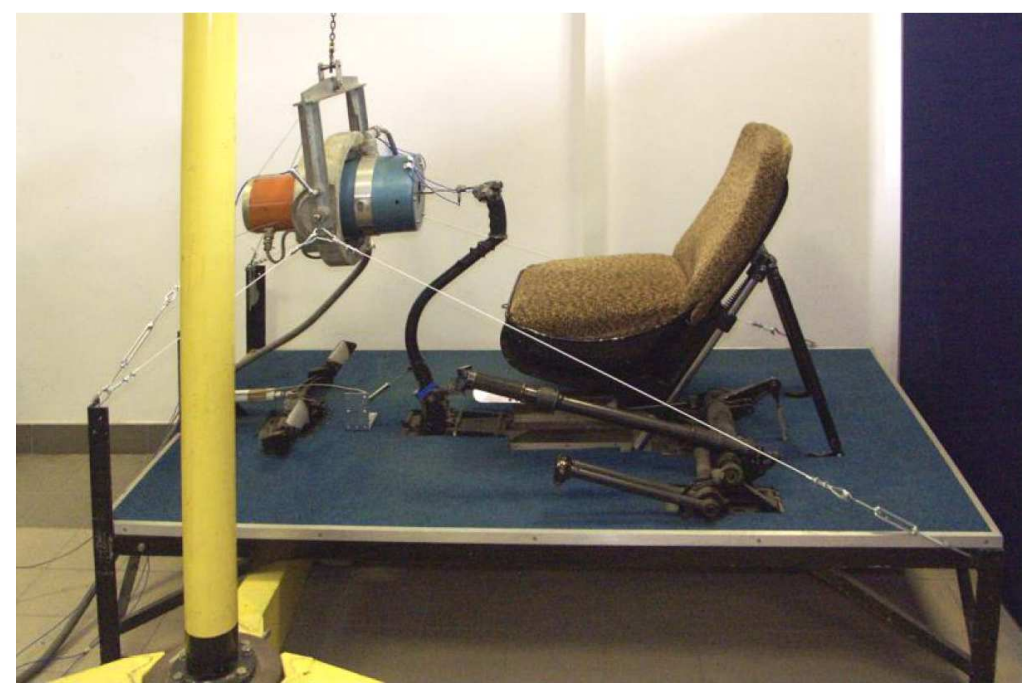

Rys. 4. Stanowisko do badania wpływu pilota na układ sterowania

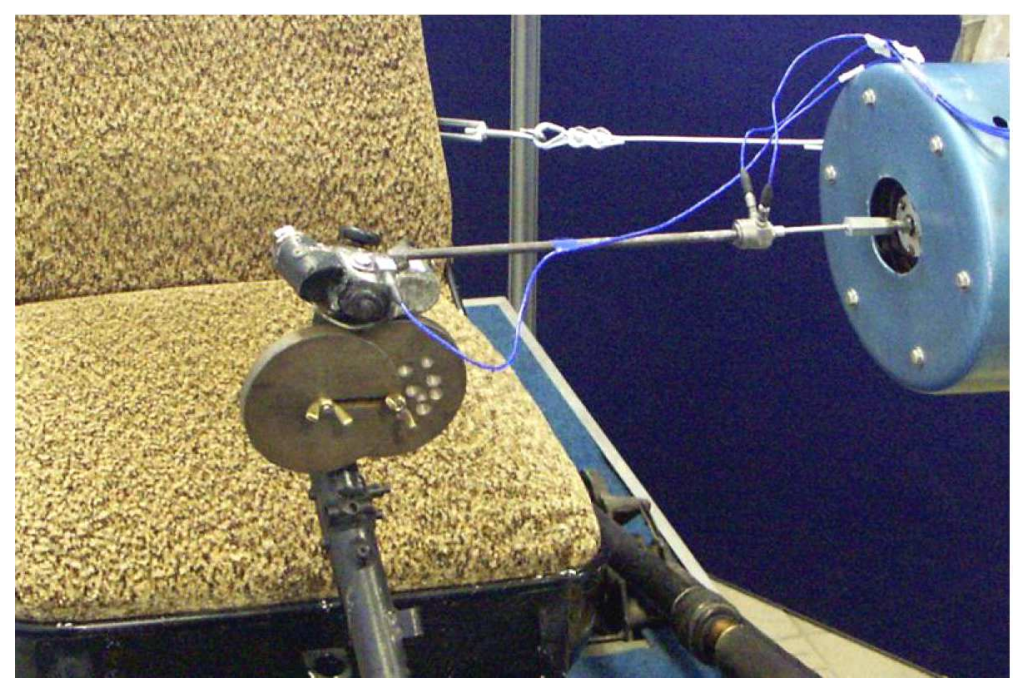

Rys. 5. Uchwyt drążka z zamocowaną masą $1 \mathrm{~kg}$ oraz czujnikiem i wzbudnikiem w układzie poprzecznym

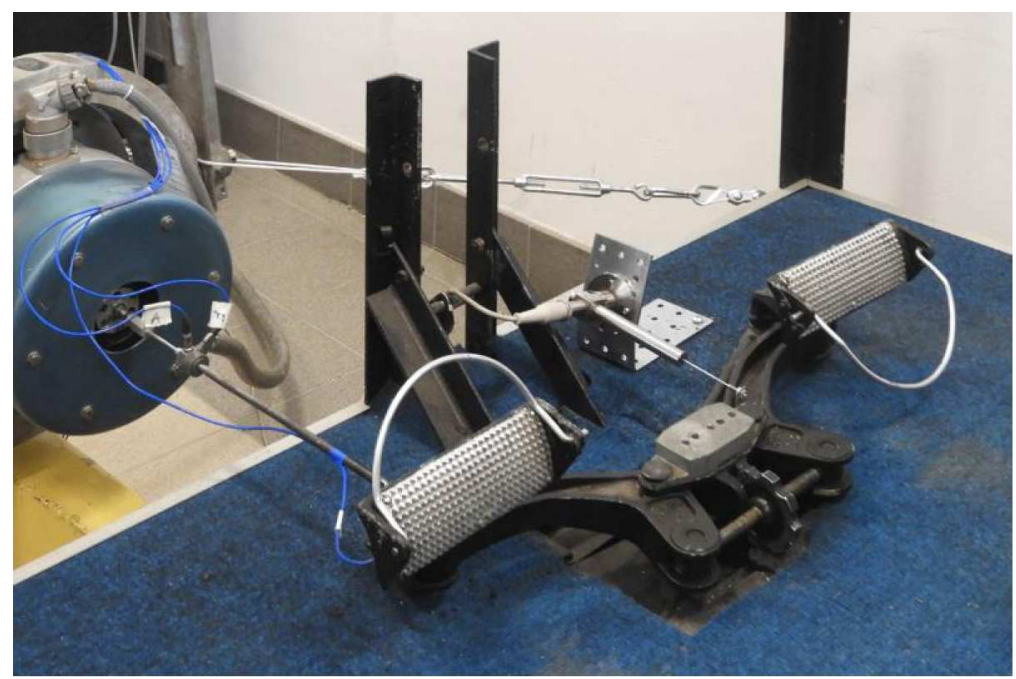

Rys. 6. Pedały przygotowane do pomiarów sterowania: lewy - stopą, prawy - nogą 
częstotliwości miało wpływ także zmęczenie biorących udział w badaniach pilotów, wynikające z utrzymania zadanych warunków przez czas trwania pomiaru.

Wyniki pomiarów były przeliczane na środek uchwytu drążka na podstawie zależności geometrycznych. Drążek oraz pedały nie miały wyczuwalnych luzów ani tarcia w przegubach.

W badaniach uczestniczyło 5 osób (o różnym wzroście i masie ciała):

- pilot szybowcowy o dużym nalocie,

- pilot samolotów lekkich i ultralekkich,

- pilot samolotów lekkich, szybowców i wiatrakowców,

- pilot poczatkujący,

- inżynier lotniczy nie będący pilotem.

Do pomiarów wykorzystano wzbudnik elektrodynamiczny o maksymalnej sile wzbudzania $200 \mathrm{~N}$ z czujnikiem siły, indukcyjny czujnik przemieszczenia i czujnik przyspieszeń oraz aparaturę i oprogramowanie firmy LMS.

\section{Wyniki pomiarów}

Wstępne pomiary miały na celu wyznaczenie masy zredukowanej drążka i pedałów stanowiska. Na podstawie wielkości częstotliwości oraz zmierzonej siły wzbudzenia i przyspieszenia (przeliczonych na podstawie zależności geometrycznych do uchwytu drążka) wyznaczono masę zredukowaną. Ze względu na amplitudę wzbudzanych drgań pomiary wykonano w zakresie częstotliwości od 8 do $20 \mathrm{~Hz}$. Pomiar masy wykonano dla samego drążka, jak i z zamocowaną do uchwytu masą 0,5 i $1,0 \mathrm{~kg}$, w celu sprawdzenia wpływu dodatkowej masy na wyniki pomiarów. Ddrążek z zamocowana masą dodatkową $1 \mathrm{~kg}$ przedstawiono na rys. 5 . Wyniki pomiarów po odjęciu dodanej do uchwytu drążka masy przedstawiają wykresy na rys. 7 .

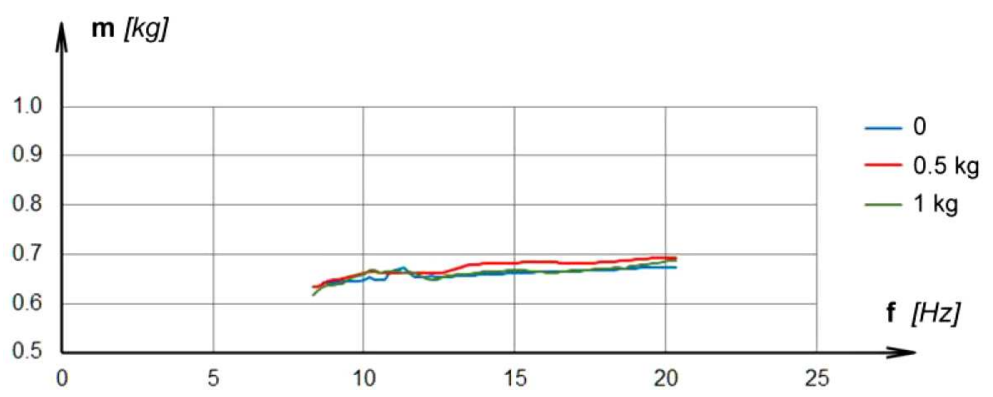

Rys. 7. Wyniki pomiarów masy zredukowanej drążka dla ruchu wzdłużnego (pochylania)

Wyznaczona w ten sposób średnia masa zredukowana drążka w kierunku wzdłużnym (pochylania) wynosiła $0,66 \pm 0,02 \mathrm{~kg}$.

Podobnie wyznaczono masę zredukowaną drążka w kierunku poprzecznym (przechylania): $0,73 \pm 0,03 \mathrm{~kg}$. Niewiele większa masa zredukowana w tym kierunku związana była z zastosowaniem dłuższego pręta łączącego wzbudnik z drążkiem $(60 \mathrm{~g})$ i z konstrukcją przegubów u podstawy drążka. Oś obrotu przechylania została wykonana $11 \mathrm{~cm}$ poniżej osi obrotu pochylania, więc ruch drążka w kierunku przechylania obejmuje także bezwładność obudowy przegubu pochylania.

W przypadku pedałów wyznaczona w ten sposób masa zredukowana układu wyniosła $0,97 \pm 0,03 \mathrm{~kg}$.

W drugim etapie wykonano badania oddziaływania pilota na drążek. Badania obejmowały 3 rodzaje działania pilota:

1 - typowe trzymanie drążka jedną ręką bez reakcji na jego drgania (bierne, odpowiadające długotrwałemu lotowi), 
2 - trzymanie drążka jedną ręką z próbą przeciwdziałania jego ruchom poprzez mocny uchwyt drążka lub usztywnienie przedramienia,

3 - trzymanie drążka przez pilota dwoma rękami z reakcją wg jego uznania, ale tak, by utrzymać drgający drążek w początkowym (zadanym) położeniu.

Dla każdego rodzaju oddziaływania drgania wzbudzano dwoma stałymi wielkościami sił: dla pochylania 5 i $10 \mathrm{~N}$ oraz dla przechylania 2 i $4 \mathrm{~N}$. Maksymalną wielkość siły w każdym przypadku dobrano tak, by w przyjętym zakresie częstotliwości amplituda drgań nie przekraczała dopuszczalnej możliwej dla wzbudnika, czyli nie więcej jak $\pm 10 \mathrm{~mm}$.

Wzbudzanie stosunkowo dużych amplitud drgań podyktowane było wywołaniem reakcji pilota na drgania steru w zakresie większym niż drgania wymuszone np. pracą silnika czy turbulentnym opływem, a także większych od drgań w zakresie nieliniowości związanych z małymi amplitudami drgań konstrukcji (np. [7]).

Częstotliwość wzbudzania była zmieniana skokowo od $20 \mathrm{~Hz}$ do $4 \mathrm{~Hz}$, z prędkością ok. 1 min/oktawę.

Na rysunku 8 przedstawiono przykładowe wykresy wyników pomiarów wielkości masy dodanej przez pilota do drążka wzbudzanego wzdłużnie oraz poprzecznie, zarejestrowane wg powyższego programu.

(a)

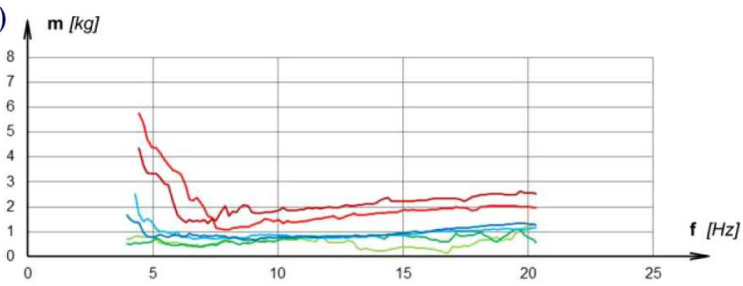

(c)

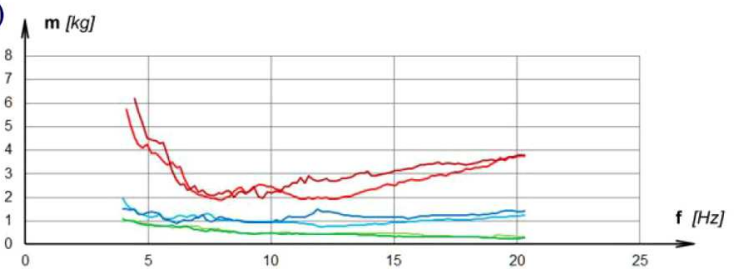

(b)

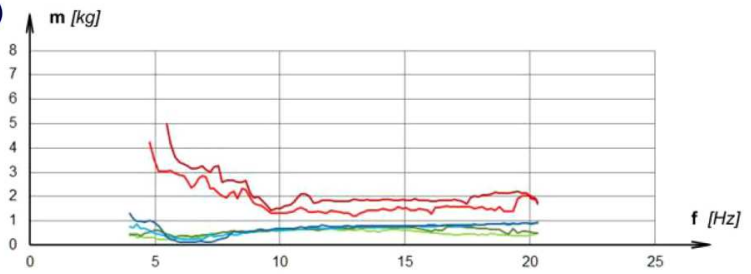

(d)

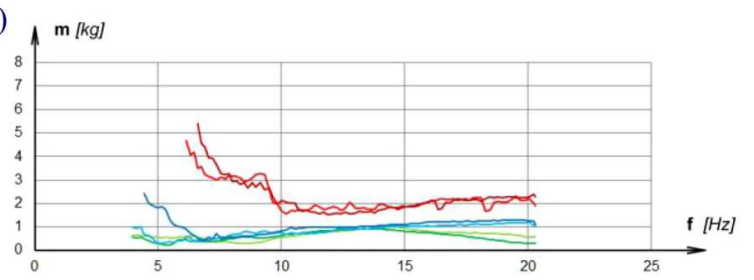

Rys. 8. Wykresy wyników pomiarów masy zredukowanej przeprowadzonych dla dwóch pilotów: (a), (c) - w kierunku wzdłużnym drążka, (b), (d) - w kierunku poprzecznym drążka

Masę zredukowaną oddziaływania pilota wyznaczono na podstawie zależności

$$
m_{z}=\frac{F}{a}-m_{d, p}
$$

gdzie: $m_{z}$ - masa zredukowana, $F$ - siła wzbudzania drgań, $a$ - przyspieszenie na drążku albo pedałach, $m_{d, p}$ - masa zredukowana drążka albo pedałów.

Każdy rysunek zawiera 6 wykresów: 2 poziomy sił wzbudzających dla trzech przypadków oddziaływania pilota. Na wszystkich wykresach dwa górne przebiegi przedstawiają wyniki dla trzymania drążka oburącz.

Wykresy przedstawiają wyniki pomiarów przeprowadzonych dla dwóch pilotów. Wyniki dla pozostałych osób niewiele różnią się od przedstawionych.

W przyjętym zakresie częstotliwości nie stwierdzono czynnej reakcji pilota jako cyklicznego przeciwdziałania siłą na drążek. Reakcją pilota ze względu na wielkość amplitudy drgań było napięcie mięśni - zwykle poniżej $10 \mathrm{~Hz}$. W zakresie powyżej $10 \mathrm{~Hz}$ masa dodana do drążka to ok. $1 \mathrm{~kg}$ dla jednej ręki (niezależnie od sposobu trzymania) i ok. $2,5 \mathrm{~kg}$ dla chwytu drążka oburącz. Relatywnie nieco większa masa dla dwóch rąk, to wynik sztywniejszego trzymania drążka, 
a przez to udział w drganiach większej części ramion i tułowia. Efekt ten w postaci wzrostu masy zredukowanej jest widoczny szczególnie dla częstotliwości poniżej $7 \mathrm{~Hz}$ dla wzbudzania wzdłużnego i poniżej $9 \mathrm{~Hz}$ dla poprzecznego.

Przebiegi wykresów dla obydwu pilotów są podobne, co świadczy o podobnej reakcji, jak i oddziaływaniu pilotów na drążek. Niewielkie różnice pomiędzy odpowiednimi parami wykresów świadczą o dobrej powtarzalności pomiarów oraz o niewielkim wpływie amplitudy drgań na wielkość wyznaczonej masy zredukowanej.

W przypadku pedałów uwzględniono dwie konfiguracje sterowania:

- pięty (obcasy obuwia pilota) opierają się o podłogę - sterowanie odbywa się stopami,

- pięty (obcasy obuwia pilota) spoczywają na podparciach przy pedałach - sterowanie nogami.

Konstrukcję pedałów umożliwiającą realizację pomiarów w tych konfiguracjach przedstawia rys. 6.

W obydwu przypadkach badania obejmowały 2 rodzaje oddziaływania pilota:

1) swobodne (bierne) ułożenie nóg lub stóp jak przy długotrwałym locie (bez reakcji na drgania),

2) czynne - jako próba przeciwdziałania drganiom pedałów poprzez nacisk na pedały lub usztywnienie mięśni nóg.

Pomiary oddziaływania pilota na pedały przeprowadzono dla większych sił wzbudzania:

- dla nóg opartych biernie $10 \mathrm{~N}$ i $20 \mathrm{~N}$, a z reakcjac pilota $20 \mathrm{~N}$ i $40 \mathrm{~N}$,

- dla stóp opartych biernie oraz z reakcją pilota $40 \mathrm{~N}$ i $80 \mathrm{~N}$.

Podobnie jak w przypadku drążka, maksymalne siły wzbudzenia dobrano tak, by amplituda drgań nie przekraczała możliwości zakresu wzbudnika (tj. $\pm 10 \mathrm{~mm})$ w przyjętym zakresie częstotliwości.

Na rys. 9 przedstawiono przykładowe wykresy wyników pomiarów wielkości masy dodanej przez pilota do pedałów zarejestrowane wg powyższego programu.
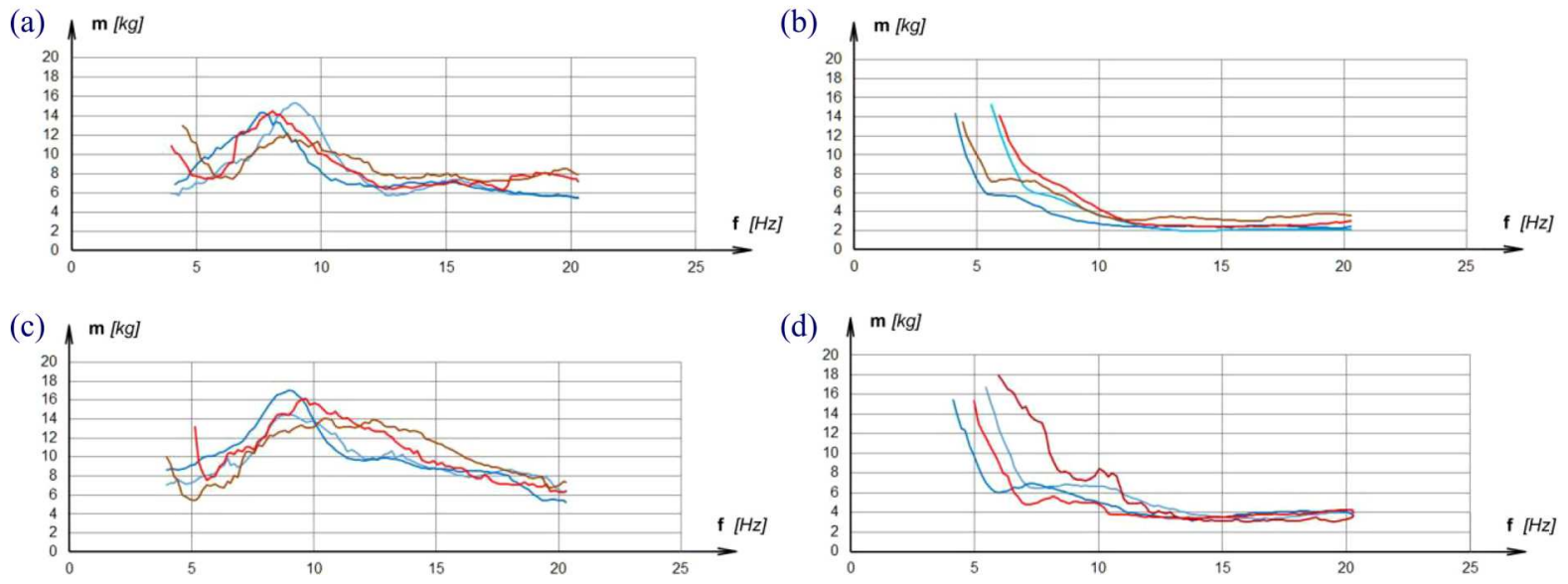

Rys. 9. Przykładowe wykresy wyników pomiarów masy zredukowanej przeprowadzonych dla dwóch pilotów: (a), (c) - przy wzbudzaniu dla nóg, (b), (d) - przy wzbudzaniu dla stóp

Każdy rysunek zawiera 4 wykresy: 2 poziomy sił wzbudzających dla dwóch przypadków oddziaływania pilota.

Podobnie jak w przypadku drążka, w przyjętym zakresie częstotliwości możliwą reakcją pilota na większą amplitudę drgań jest napięcie mięśni nóg - występuje ona poniżej $12 \mathrm{~Hz}$. W badanym zakresie całkowita masa dodana do pedałów to ok. 7-14 kg przy sterowaniu nogami. Przebieg 
wykresów wskazuje na niewielki wpływ reakcji pilota (napięcia mięśni) na drgania, jak również na mały wpływ amplitudy drgań na wielkość masy dodanej przez pilota. W zakresie mniejszych częstotliwości nieco większa masa dodana przez drugiego pilota (rys. 9c i 9d) odpowiada jego nieco większej masie ciała (w szczególności nóg) w stosunku do pierwszego pilota (rys. 9a i 9b).

W przypadku sterowaniu stopami całkowita masa dodana do pedałów to ok. $3-4 \mathrm{~kg}$, a reakcja poprzez napięcie mięśni i nacisk na pedały (a przez to wzrost masy dodanej) występuje poniżej $8 \mathrm{~Hz}$, osiągając wielkość nawet kilkunastu kilogramów.

Na wyniki pomiarów masy zredukowanej rąk czy nóg w zakresie częstotliwości poniżej $7 \mathrm{~Hz}$ ma wpływ tłumienie stawów (nadgarstka, łokcia, kolan) oraz tułowia. Jego wielkość nie była mierzona, jednak dodatkowe tłumienie zwykle poprawia właściwości flatterowe konstrukcji (zwiększone tłumienie danej postaci drgań).

\section{Wnioski}

- Wykonane pomiary pozwoliły ustalić wielkość masy dodawanej przez pilota do układów sterowania w zakresie częstotliwości odpowiadających lekkim konstrukcjom latającym, jak szybowce, samoloty lekkie i ultralekkie, wiatrakowce lub małe śmigłowce.

- Masa dodana do drążka przez pilota w zakresie częstotliwości 7-20 Hz niewiele zależy od częstotliwości i od sposobu trzymania drążka przez pilota, natomiast zależy od tego, czy drążek jest trzymany jedną czy dwoma rękami. W przypadku pedałów wielkość dodanej masy zależy głównie od sposobu oparcia stopy.

- Na wielkość masy zredukowanej w zakresie niskich częstotliwości (poniżej $7 \mathrm{~Hz}$ dla drążka i poniżej $10 \mathrm{~Hz}$ dla pedałów) ma wpływ sztywność i tłumienie wprowadzane przez ciało pilota.

- Przeprowadzone badania wpłynęły na zmianę ramowego programu badań rezonansowych płatowców. Obecnie podczas wyznaczania częstotliwości i postaci drgań powierzchni sterowych uwzględnia się 2 wielkości mas zastępczych dokładanych do drążka (oprócz przypadku bez masy).

- W przypadku pedałów masa dokładana zależy od częstotliwości wychylania steru kierunku, a także od rodzaju pedałów (sterowanie nogami czy stopami).

- Wyniki pomiarów pozwalają na dokładniejsze uwzględnienie wpływu pilota na układy sterowania, przez co umożliwiają zwiększenie dokładności obliczeń prędkości krytycznej flatteru z udziałem powierzchni sterowych.

\section{Bibliografia}

1. Przepisy CS-23 - Specyfikacje certyfikacyjne dla samolotów kategorii normalnej, użytkowej, akrobacyjnej i transportu lokalnego

2. ČEČRdLe J., HLAVATÝ V., Aeroelastic certification of light sport aircraft according "LTF regulation", 18th International Conference Engineering Mechanics, 169-176, 2012

3. Rogólski R., Olejnik A., Structural model with controls of a very light airplane for numerical flutter calculations, Aircraft Engineering and Aerospace Technology, 92, 3, 304-317, 2018

4. Krzymień W., Badania dowodowe wiatrakowca I-28 w kategorii „Specjalny” na zgodność z przepisami ASTM, Prace Instytutu Lotnictwa, 236, 41-48, 2014

5. Mattabon M., Fumagalli A., Jump M., Masarati P., Quaranta G., Biomechanical pilot properties identification by inverse kinematics/inverse dynamics multibody analysis, 26. ICAS, 2008

6. KIESsLing F., On simplified analytical flutter clearance procedures for light aircraft, Forschungsbericht DLR-FB, 89-56, 1989 
7. Krzymień W., Nieliniowości częstotliwości drgań rezonansowych lekkich płatowców, Prace Instytutu Lotnictwa, 220, 77-83, 2011

\section{Pilot's impact on vibration properties of the light aircraft control system}

Analysis of aeroelastic properties of flying structures is required by airworthiness regulations. The part of analysis are resonance tests (GVT) of the structure, the results of which are needed for flutter calculations and also the basis for conducting tests in flight. Resonance testing includes tests of control systems for tilting or twisting of steering surfaces. In the case of light and ultralight designs, the pilot's impact can significantly change vibration properties of the control system. The tests carried out were aimed at determining the influence of the pilot on the control system by applying mass of the hand and stiffness of the arm to the stick and legs to the pedals. The results of measurements allow the replacement mass of the hand or hands and legs to be taken into account during ground vibration tests (GVT) and in calculation of the flutter properties of lightweight structures. The article presents the measurement method and some results of experiments carried out at a specially prepared test stand. 